\title{
MRS Committee Goals
}

\section{Awards, Corporate Participation, External Affairs, Long Range Planning, Membership, and Program Committees Set 1987 Priorities}

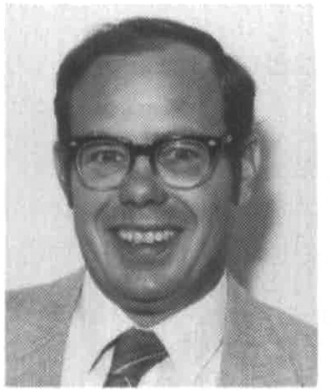

G. E. Pike

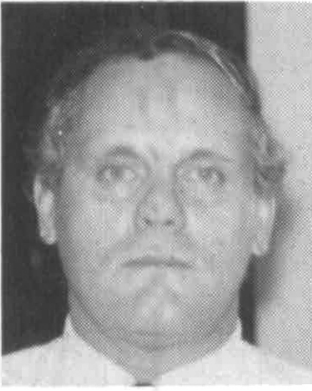

L. M. Quick

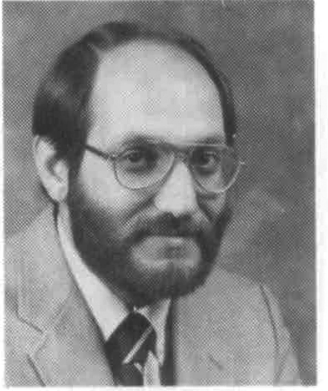

E. N. Kaufmann

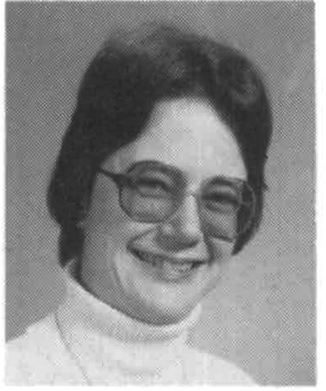

J. M. Phillips

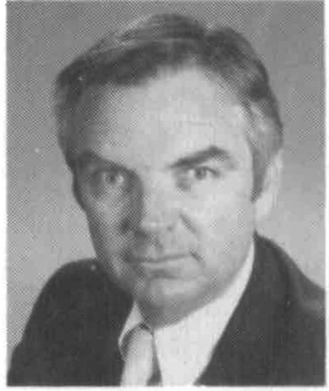

R. K. Quinn
In the previous issue of the MRS BULLETIN (p. 4), MRS President Kathleen C. Taylor announced appointments of the 1987 chairs for the Society's 11 committees. Below is a summary of the goals and activities of six of the committees as defined by their chairs.

The work of the committees sustains the myriad of professional services offered to MRS members. As the Society continues to experience a high level of growth - in numbers of members and in interests and needs - the committees play an important role in instituting new dimensions for existing projects and in recommending changes in policies and procedures to the MRS Council. MRS members are encouraged to contact committee chairs to offer advice, suggestions, or assistance.

\section{Awards Committee}

Chair: Gordon E. Pike, Sandia National Laboratories, Albuquerque, NM; Telephone (505) 844-7562

The Awards Committee is responsible for soliciting nominations for the Von Hippel Award which is conferred at the Fall Meeting, and for the Graduate Student Awards which are presented at both the Spring and Fall Meetings. This committee is one of three chaired ex officio by the Immediate Past President of the Society. As in the past, this committee will continue to seek nominations of materials scientists with exemplary interdisciplinary careers for the Von Hippel Award. However, this year a new responsibility has been added. At the Fall 1986 MRS Council Meeting, the President was directed to establish a select standing subcommittee, with the advice and consent of Council, to evaluate nominations and make written recommendations to the full Council for their final and decisive vote. The members of this subcommittee will be determined by Council later this Spring. In a move to further highlight this award, Council also authorized an increase in the monetary prize from $\$ 2500$ to $\$ 5000$ for future laureates. Additional information concerning the Von
Hippel Award and its nomination procedures can be found elsewhere in this issue of the BULLETIN.

MRS believes it is important to recognize outstanding research by graduate students. In 1980 the Society created an active Graduate Student Awards program for students participating in one or more of the symposia at a given meeting. The Awards Committee will administer these awards by promoting the award, soliciting nominations, and evaluating the submitted support material with the aid of relevant symposium chairs. The committee will also review and establish the general qualifications for the award, and its monetary prize level.

The Awards Committee will be working with the Long Range Planning Committee to determine whether additional forms of recognition should be instituted, and how they might be supported.

\section{Corporate Participation Committee Chair: L. Michael Quick, Engelhard Corporation, Edison, NJ; telephone} (201) 321-5590

The Corporate Participation Committee is the interface between MRS and its Corporate Affiliates. The Corporate Affiliates play a vital role in the Society by ensuring that the Society's technical programs are responsive to the interests of the corporate materials research community. The committee is responsible for keeping the Corporate Affiliates abreast of MRS activities, for seeking their advice on topics to be addressed at its meetings, and for broadening the base of support for MRS and its activities in the corporate sector.

MRS corporate participants number more than 100, and the committee plans to step up activities to introduce the program and its benefits to additional companies. The committee has recently prepared an updated information sheet which outlines the newest Corporate Affiliate benefits and lists the companies presently involved in the program.

\section{External Affairs Committee}

Chair: Elton N. Kaufmann, Lazurence Livermore National Laboratory, Livermore, CA; telephone (415) 423-2640

The External Affairs Committee of MRS is only three years old. Under the chairmanship of R.L. Schwoebel (Sandia National Laboratories) in 1985 and F.W. Young, Jr. (Oak Ridge National Laboratory) in 1986, the activities of the committee expanded rapidly. This was due in part to the significant investment of effort and enthusiasm by the chairmen and committee members. It was also a consequence of the rapidly growing recognition of MRS within the materials community and related public and private institutions. The committee's charter is broad. It is an inter face between MRS and all other bodies. Some specific areas are, of course, already handled by other MRS committees such as Corporate Participation (industries), Public Relations and Publicity (press), Education (universities), and Program (other conference planning groups). The focus thus far in External Affairs is therefore directed at government relations, intersociety relations, and international relations. The subcommittees on intersociety relations and international relations are chaired by Gordon E. Pike (Sandia National Laboratories) and R.P.H. (Bob) Chang (Northwestern University), respectively. Government relations is attended to by Elton N. Kaufmann (Lawrence Livermore National Laboratory).

A de facto tradition of MRS during its more formative years was to delegate to the Immediate Past President much of the lead responsibility for what is now called external affairs. Today's committee includes four past presidents of MRS: J.M. Poate (AT\&T Bell Laboratories), C.W. White (Oak Ridge National Laboratory), Gordon Pike, and Elton Kaufmann, so that continuity and familiarity with MRS styles and goals is maintained. 
Much of the "product" which results from the work of this committee is intangible. It consists primarily of ad hoc and informal discussions with representatives of other societies, government agencies, various panels and study groups, and members of the international community - all serving to increase the understanding of MRS programs, to identify and enhance the contributions MRS might make to the needs and goals of sister organizations, and to bring to MRS members an ever wider circle of colleagues in materials research who influence the pursuit of our profession. Based on these interactions, the committee formulates advice to the MRS Council and Executive Committee.

Some tangible past accomplishments can, however, be noted. MRS has cosponsored a variety of symposia and meetings with other societies; it has responded to requests from the National Science Foundation to contribute evidence of the value of supported research; it has spawned a sister society in Europe (European MRS) and is actively nurturing relationships with such counterparts in Asia, Australia, India, and Latin America; it has hosted materials community dialogues on "large facilities" issues and on "community representation" issues; it has reached reciprocal agreements on society publications; and it has produced the highly successful Forum on the national MSE Study at the 1986 MRS Fall Meeting.

What is past is indeed prologue. MRS, through the efforts of the External Affairs Committee and many other MRS volunteers, will continue such activities in 1987. Emphasis will continue to be on the international scene through participation in an MRS International Committee and collaboration on planning MRS style meetings in Japan (1988) and elsewhere. Also emphasized will be MRS efforts to support the MSE Study and enhance communication channels within the materials community through more cooperative programs with other societies and ad hoc events bringing community members in touch with the patrons of materials research.

Long Range Planning Committee Chair: Gordon E. Pike, Sandia National Laboratories, Albuquerque, NM; telephone (505) $844-7562$

Organizations, like people, can enter the future with or without plans. In the latter case life proceeds reactively, responding to immediate needs and opportunities. With plans one tries to follow a course based on anticipated needs and created opportunities. While "a little chaos is a good thing," (E.N. Kaufmann, MRS BULLETIN Vol. X No. 3, 1985, p. 3) MRS must do some advanced planning in order to have the human and financial resources available to effectively serve the materials research community. There are two major aspects of this service. The first is trying to discern just what the future needs and opportunities of this community really are. The other is determining Society priorities while attempting to meet them with a limited amount of human and financial resources. The difficulty with resource allocation is compounded for MRS by its rapid growth and consequent uncertainty of what resources will be available in the next five years. To cope with these issues, MRS has a Long Range Planning Committee, which is chaired ex officio by the Immediate Past President. For 1987 Gordon Pike has subdivided the responsibility of this committee into several specific categories, each to be considered by a subcommittee.

David Biegelsen (Xerox PARC) will head a subcommittee to consider the appropriate balance of possible activities in which MRS could be involved. Such activities include technical meetings (domestic and international), workshops, short courses, and publications. David Campbell (IBM East Fishkill) will chair a group specifically concerned with the type, quality, and quantity of publications from the Society within the next five years. Electronic communications goals for MRS officers, com- mittee chairs, and general membership is to be handled by a small subcommittee under Clyde Northrup (Sandia National Laboratories). Issues of university faculty involvement with the Society will be addressed by Richard Osgood (Columbia University) and his group, while MRS interactions with educator organizations will be investigated by a subcommittee chaired by Rod Ewing (University of New Mexico). The future operation of our awards program is an assignment accepted by Bill Appleton (Oak Ridge National Laboratory) and his group. Past treasurer, Clif Draper (AT\&T Technologies) will head a subcommittee to examine the financial future of the Society in terms of varied income sources and overall budgetary guidance. Gordon Pike (Sandia National Laboratories) will chair a task force to determine the headquarters staff and space requirements for anticipated activities, and whether the Society should purchase a headquarters building or continue to lease space. Finally, the considered plans from the above subcommittees will be integrated with other previous and ongoing determinations into

Continued

\section{MATERIALS RESEARCH SOCIETY 1987 Committee Chairs}

Committees

Corporate Participation

External Affairs

Program

*EducationShort Courses

EducationUniversity Issues

*Public Relations

\& Publicity

Membership

*Finance

Awards

Long Range Planning

*Nominating

\section{Chaired or Cochaired by}

L.M. Quick, (201) 321-5590

E.N. Kaufmann, (415) 423-2640

R.K. Quinn, (505) 667-6250.

J.B. Roberto, Vice Chair, (615) 576-0227

A.D. Romig, Cochair, (505) 844-8358

G. Tibbets, Cochair, (313) 986-0655

C.M. Jantzen, (803) 725-2374

J.M. Phillips, (201) 582-4428

C.W. Draper, (609) 639-2350

G.E. Pike, (505) 844-7562

G.E. Pike, (505) 844-7562

G.E. Pike, (505) 844-7562 
a Five-Year Plan for MRS by a group under John Baglin (IBM T.J. Watson Research Center). Baglin also has the responsibility for monitoring the growth of all Society activities so that reasonable projections based on the current mode of operations can be made.

\section{Membership Committee}

Chair: J.M. Phillips, ATET Bell Laboratories, Murray Hill, NJ; telephone: (201) 582-4428

The Membership Committee, chaired by the Secretary of the Society, is responsible for overseeing the needs of the MRS membership. Some of the member services overseen by the Membership Committee include the publication of the MRS Membership Directory and oversight of the MRS Job Placement Center held at the Fall and Spring Meetings. The committee is involved in efforts to form local MRS Sections around the country. While MRS has grown rapidly over the years, there are still many who are not familiar with the purpose and goals of the Society. With this in mind, the committee will launch a vigorous membership campaign in an effort to increase participation in the Society. During 1987, the Committee will review member benefits and prepare additional proposals for Council so that MRS can continue to be responsive to the needs of the membership.

\section{Program Committee}

Chair: Rod K. Quinn, Los Alamos National Laboratory, Los Alamos, NM; telephone

(505) 667-6250. Vice Chair: Jim B. Roberto, Oak Ridge National Laboratory, Oak Ridge, TN; telephone (615) 574-4327

The Program Committee serves one of the most important functions in MRS. We have responsibility for selecting topics and organizers for future MRS meetings and coordinating the organization of these meetings. It is our intent to maintain high quality in truly multidisciplinary topics of new and exciting areas of materials research. The programs for Spring 1987 and Fall 1987 are being finalized and they are excellent, led by outstanding meeting chairs.

In the coming year, the Program Committee will address the issues that confront a mature MRS as they relate to support of our meetings. We must realistically address funding of MRS meetings now that meeting registration fees contribute a decreasing share of the Society budget. The committee has taken on as a project the production of a written guide that will assist meeting chairs and symposium chairs in organizing their programs, especially in how they can effectively work with MRS headquarters and our meeting planners who turn their programs into an MRS meeting.
The Program Committee has been tasked by the MRS Council to examine the nature and content of our increasingly successful meetings. J.B. Roberto has agreed to chair a five-person subcommittee that will address technical program development and program issues. Within the year this subcommittee will communicate specific recommendations to the Program Committee, and identify programming issues in need of consideration by the Council.

In the area of technical program development the subcommittee will identify new areas of materials research appropriate for future consideration, identify specific "hot" topics for future symposia, prepare suggested symposia lists for meeting chairs, and assist meeting chairs in selecting symposium chairs. Technical program issues of continuing concern are meeting size and location, broad topical coverage, and invited speaker selection.

Also, Jim Roberto has agreed to serve in the newly defined position of vice-chair of the Program Committee and will assume the chairmanship in 1988. Since we are planning meetings 24 months ahead, this procedure allows for continuity that cannot be achieved with a yearly turnover in the Program Committee leadership.

MRIS

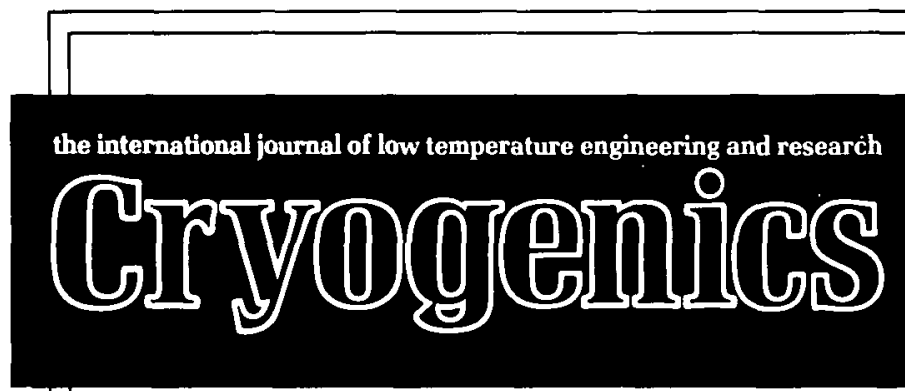

Cryogenics is the internationally

established journal which provides a

forum for papers concerned with

cryoengineering and cryophysics. As the

world's leading low temperature

engineering and research journal it is essential reading for all those working in this field in industry and academia.

Apart from original research papers,

Cryogenics also includes commissioned review articles, research and technical notes, letters to the editor, calendar, conference reports and a news section. $A$ high standard of published material is assured by an international board of distinguished scientists and engineers

Typical subject areas include:

Thermodynamics

- Fluid properties and fluid mechanics

Heat transfer

- Refrigeration and liquefaction technology

- Ultra-low temperatures

- Properties of materials: metals, alloys, composites, polymers, insulations

- Superconductors and their properties

- Applications of superconductivity: magnets, electronics, devices

- Thermometry and measurement science

- Cryogenics in medicine

- New applications of cryogenic technology to processes, devices, machinery

For further details and a sample copy please contact: Sheila King, Butterworth Scientific Limited, PO Box 63, Westbury House, Bury Street, Guildford, Surrey GU2 5BH, UK. Telephone 048331261 Telex 859556 SCITEC G 